\title{
Accuracy characteristics of object location in a two-position system of small onboard radars
}

\author{
A. P. Shepetaa, Dr. Sc., Tech., Professor, orcid.org/0000-0003-0179-0166, alex@shepeta.com \\ V. A. Nenasheva, PhD, Tech., Associate Professor, orcid.org/0000-0001-5285-2051 \\ a Saint-Petersburg State University of Aerospace Instrumentation, 67, B. Morskaia St., 190000, \\ Saint-Petersburg, Russian Federation
}

\begin{abstract}
Introduction: The search for physical objects in a given area is often performed in automatic mode using small unmanned aerial vehicles equipped with radars. Airborne radar antennas, due to size restrictions, have a small aperture and, accordingly, a wide directional pattern, decreasing the accuracy of determining the angular coordinates of the objects. The increase in the angular coordinate estimation accuracy leads to the increase in the informativeness of such automatic search systems and, consequently, to the increase in the efficiency of their practical use. Purpose: Developing a technique for calculating the parameters of a two-position radar system consisting of two small airborne radars placed on small unmanned aerial vehicles, in order to increase the accuracy of determining the angular coordinates of radiocontrast physical objects. Results: An algorithm is proposed for integrating the data about the coordinates of physical objects detected in the joint coverage area of a two-position system of small airborne radars. It allows you, depending on the observation conditions, to increase the accuracy of determining the azimuthal coordinates by an order of magnitude or more. The aircraft trajectories are calculated on which the accuracy grows, and those on which there is almost no gain in accuracy. Practical relevance: Such two-position airborne small radars can be used in automated systems in order to detect physical object such as people in disaster areas, as well as in systems of collecting and processing data from sensors used for monitoring the state of the environment or man-made objects.
\end{abstract}

Keywords - two-position system, airborne radars, coordinate measurement, accuracy characteristics, small aerial vehicles, antenna aperture, directional pattern, integration.

For citation: Shepeta A. P., Nenashev V. A. Accuracy characteristics of object location in a two-position system of small onboard radars. Informatsionno-upravliaiushchie sistemy [Information and Control Systems], 2020, no. 2, pp. 31-36. doi:10.31799/1684-8853-2020-2-31-36

\section{Introduction}

Recently much attention has been paid to the use of unmanned aerial vehicles (UAV) in various spheres of human activity, such as ecological monitoring, geological exploration, cartography, sensor data reading, searching for people in disaster areas, etc. [1-11]. In all these cases, UAVs are used as a part of a more complex system for automated or automatic execution of the above tasks. The first-priority tasks are those of detecting physical objects, sensors or people in a given search area, determining their coordinates with a rather high accuracy [12-15].

The most common onboard equipment of such UAVs are small airborne radars (AR) which determine the range and azimuth of the detected objects in a polar coordinate system associated with the UAV. The peculiarity of small UAV onboard equipment is that the antenna systems of such AR have a small size and, hence, a wide directional pattern, which does not allow individual UAVs to achieve high accuracy in determining the direction to the detected object.

This drawback can be overcome by using the idea of a multistatic radar [16-18], having at least two split radio data sources. In particular, two-position systems [19-21] with two UAVs are the simplest and most acceptable way of overcoming the limitations of a unistatic small AR. This article discusses the possibilities of a two-position AR complex in terms of improving the accuracy of determining the azimuth-range coordinates of physical objects detected in the joint coverage area of small UAVs combined in a two-position small radar system.

\section{Statement of the problem}

Two small UAVs equipped with identical small radars which are united (during the data exchange) into a two-position radar system are flying at the same altitudes $H$, with the same speeds $V$, along parallel trajectories separated by the distance $D=2 \Delta$, searching for physical objects in their joint coverage area whose center is at the same distance $L$ from each UAV. Fig. 1 illustrates the described situation.

The antennas are directed towards the center (C) of the joint coverage area. The antenna beam width at the half-power level is equal to $\Delta \varphi$. Let us assume that $H / L<<1$, because in practice this inequality is most often true, as UAVs usually fly at low altitudes. A simplification like this is not essential; all the conclusions are still valid without this restriction, but it allows us to reason in planimetric terms, significantly simplifying all the expressions below. 


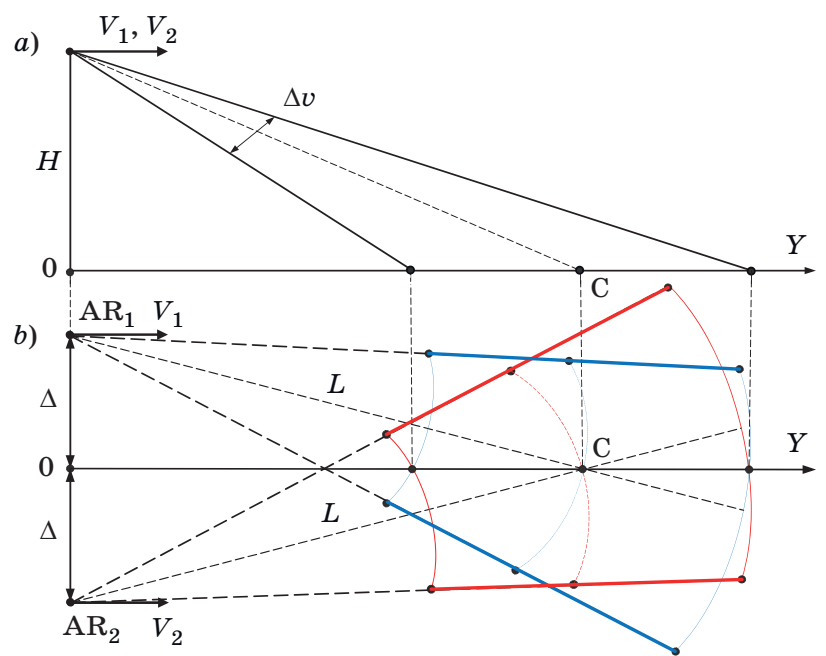

Fig. 1. Joint coverage area of a two-position small radar

A planimetric illustration with these limitations is shown in Fig. 2, demonstrating the range tracks of each AR. When each radar operates in a standalone mode, the coordinates of the detected physical object (PO) are estimated independently. In this case, the range to the object is determined by the number of the corresponding range track, and the azimuthal coordinate coincides with the direction of the maximum of the directional pattern [20].

Thus, in the case of standalone operation of a radar, the accuracy of estimating the range to a radiocon- trast object is determined mainly by the range track width, depending on the probe pulse duration. The accuracy of the azimuthal coordinate estimation is determined by the actual width of the directional pattern of the UAV antenna system [22-26]. Therefore, in the case of standalone operation, the range to the PO can be determined with the required accuracy (by changing the duration of the probe pulses), but the azimuthal coordinates are determined too roughly, with the actual accuracy equal to $\Delta \varphi / 2$. Narrowing the width of the directional pattern is difficult, firstly, due to the size limitations on a UAV antenna, and secondly, due to the reduction of the search area size.

Combining two UAVs into a single two-position radar system in which the radars exchange data [20, 27-30] allows you to improve the accuracy of determining the azimuthal coordinates of a PO detected in the joint coverage area.

\section{Interval estimation of the detected object azimuth in a two-position system of small radars}

In this subsection, we use the notation and formulas obtained in [20]. Let us assume that two $\mathrm{AR}_{1}$ and $\mathrm{AR}_{2}$ of a two-position system have detected, in their joint coverage area, a physical object at the distance $R_{1}$ from $\mathrm{AR}_{1}$ and distance $R_{2}$ from $\mathrm{AR}_{2}$, as shown in Fig. 3.

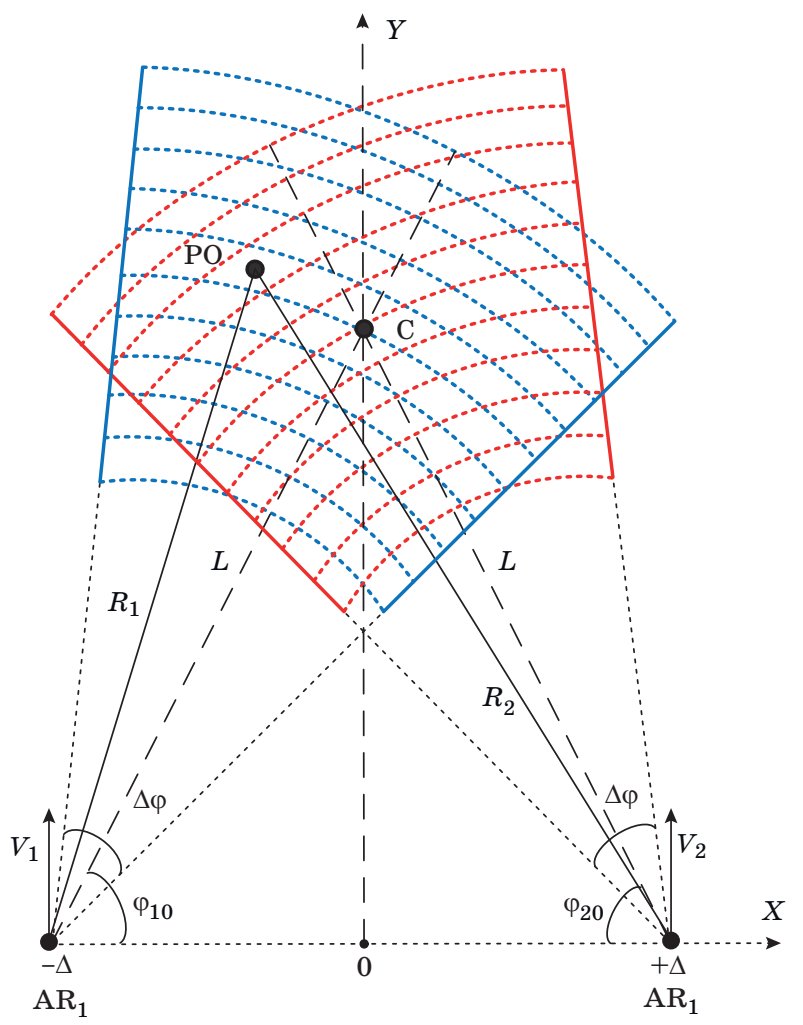

Fig. 2. Resolution elements of a two-position small radar

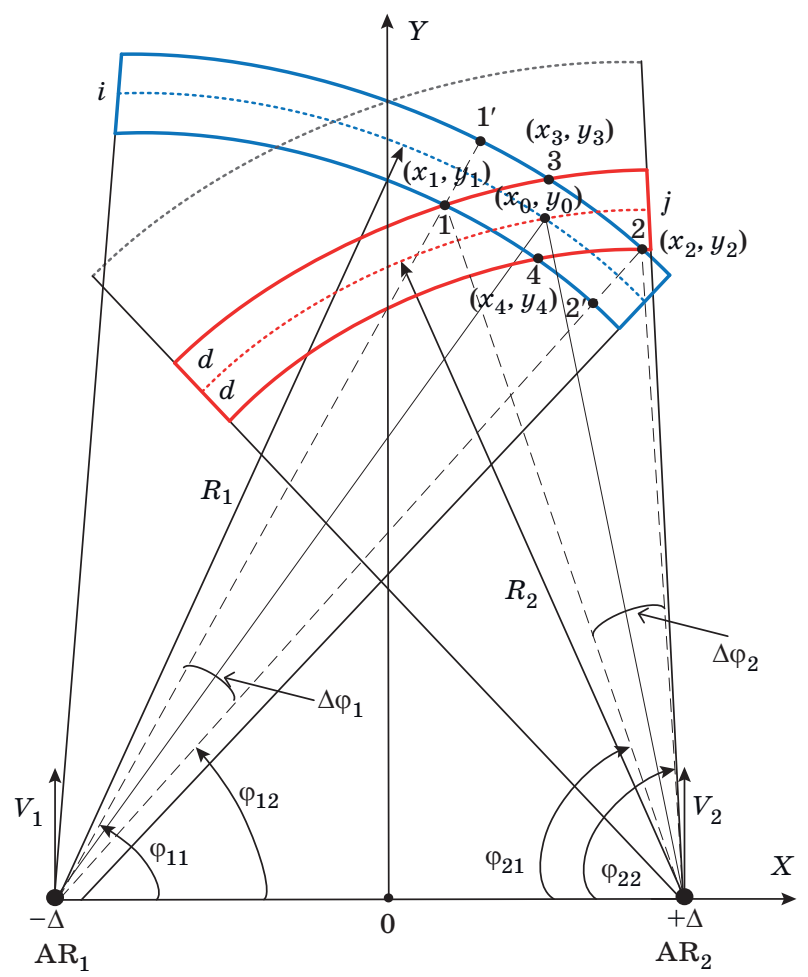

Fig. 3. Interval estimation for the azimuth of the $(i, j)$ th resolution element 
This physical object is located in the $(i, j)$-th resolution element of the system highlighted in Fig. 3, on the $i$-th track of the $A_{1}$ range and $j$-th track of the $\mathrm{AR}_{2}$ range. The figure shows the distances to the middle of the range tracks, each the size of $d_{0}=2 d=\tau_{i m} c / 2$, as well as the coordinates of the center $\left(x_{0}, y_{0}\right)$ and the boundary points of the resolution element $\left(x_{1}, y_{1}\right),\left(x_{2}, y_{2}\right)$. In [20], the coordinates of the boundary points of the resolution element are obtained:

$$
\begin{aligned}
& \left\{\begin{array}{l}
x_{0}=\frac{R_{1}^{2}-R_{2}^{2}}{2 D}=\frac{\left(R_{1}-R_{2}\right)\left(R_{1}+R_{2}\right)}{2 D}, \\
y_{0}=\frac{1}{2 D} \sqrt{\left[D^{2}-\left(R_{1}-R_{2}\right)^{2}\right]\left[\left(R_{1}+R_{2}\right)^{2}-D^{2}\right]} ;
\end{array}\right. \\
& \left\{\begin{array}{l}
x_{1}=x_{0}-\frac{d}{D}\left(R_{1}+R_{2}\right), \\
y_{1}=y_{0} \sqrt{\left[1+\frac{d_{0}}{D-\left(R_{1}-R_{2}\right)}\right]\left[1-\frac{d_{0}}{D+\left(R_{1}-R_{2}\right)}\right]} ; \\
y_{2}=y_{0} \sqrt{\left[1-\frac{d_{0}}{D-\left(R_{1}-R_{2}\right)}\right]\left[1+\frac{d_{0}}{D+\left(R_{1}-R_{2}\right)}\right]}
\end{array}\right.
\end{aligned}
$$

From expressions (2) and (3), we can directly derive the angular size of the $(i, j)$-th resolution element $\Delta \varphi_{1}$ for $\mathrm{AR}_{1}$ and $\Delta \varphi_{2}$ for $\mathrm{AR}_{2}$ [20]:

$$
\left\{\begin{array}{l}
\Delta \varphi_{1}=\operatorname{arctg}\left(\operatorname{tg}\left(\varphi_{11}-\varphi_{21}\right)\right)= \\
=\operatorname{arctg} \frac{y_{1}\left(\Delta+x_{2}\right)-y_{2}\left(\Delta+x_{1}\right)}{y_{1} y_{2}+\left(\Delta+x_{1}\right)\left(\Delta+x_{2}\right)}, \\
\Delta \varphi_{2}=\operatorname{arctg}\left(\operatorname{tg}\left(\varphi_{22}-\varphi_{12}\right)\right)= \\
=\operatorname{arctg} \frac{y_{2}\left(\Delta-x_{1}\right)-y_{1}\left(\Delta-x_{2}\right)}{y_{1} y_{2}+\left(\Delta-x_{1}\right)\left(\Delta-x_{2}\right)}
\end{array} .\right.
$$

Expressions (4) are what actually determines the angular resolution of this two-position system, because in the considered situation they actually are interval estimations of the azimuthal coordinates of the object detected in the $(i, j)$-th resolution element.

\section{Dependence of the resolution on the probe pulse duration and direction to the object}

Figures $4, a$ and $b$ show the dependences of resolutions $\Delta \varphi_{1}$ and $\Delta \varphi_{2}$ of a two-position system of small $\mathrm{AR}$ on the direction to the detected object, for two durations of the probe pulse and three range tracks: the central one passing through the center of the joint coverage area, the close one spaced away from the coverage area center by -2500 meters, and the
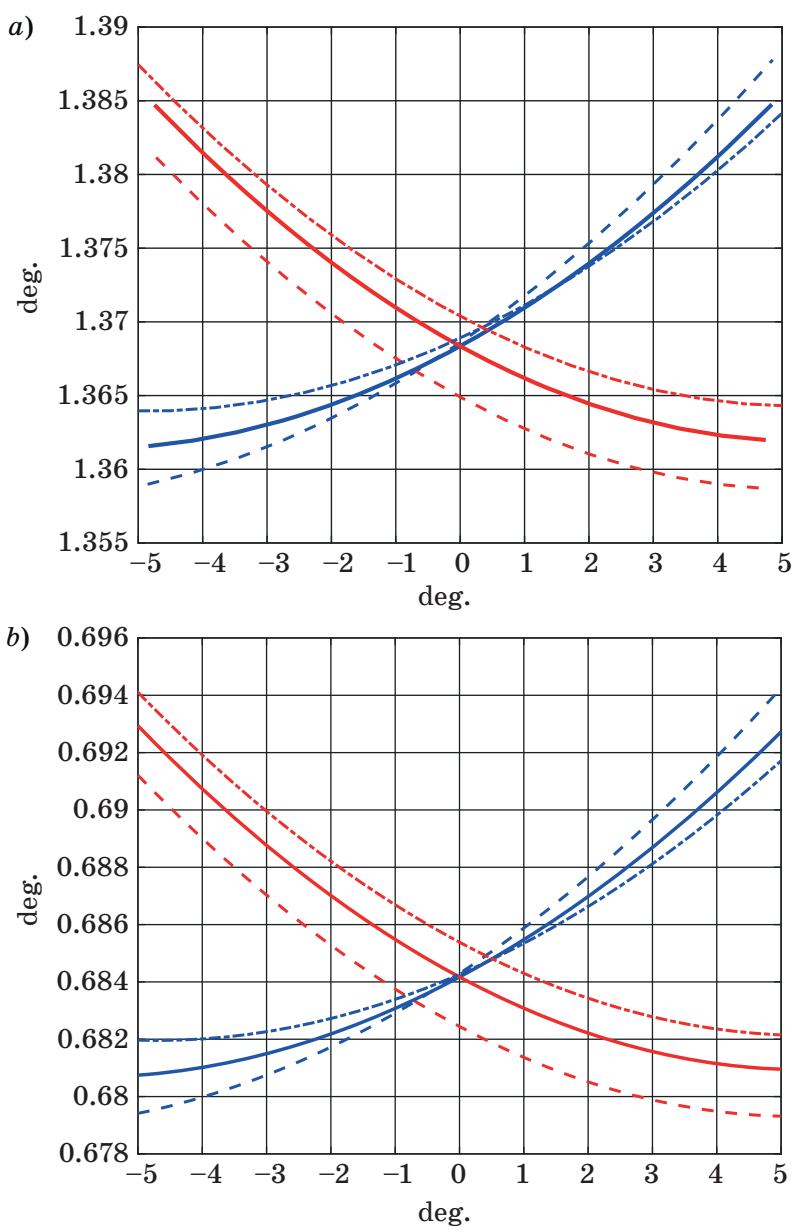

- $\mathrm{AR}_{1}$ Near zone $\mathrm{OX}=22.5 \mathrm{~km}$
- $\mathrm{AR}_{2}$ Near zone $\mathrm{OX}=22.5 \mathrm{~km}$
- $\mathrm{AR}_{1}$ Central zone $\mathrm{OX}=25 \mathrm{~km}$
- $\mathrm{AR}_{2}$ Central zone $\mathrm{OX}=25 \mathrm{~km}$
---- $\mathrm{AR}_{1}$ Far zone $\mathrm{OX}=27.5 \mathrm{~km}$
---- $\mathrm{AR}_{2}$ Far zone $\mathrm{OX}=27.5 \mathrm{~km}$

Fig. 4. Dependence of two-position system resolution on the direction to the object for $\Delta \varphi=12.5^{\circ}$ and $D=5 \mathrm{~km}$ : $a-\tau_{i m}=0.4 \mu \mathrm{s} ; b-\tau_{i m}=0.2 \mu \mathrm{s}$

far one spaced away from the coverage area center by +2500 meters.

The direction to the object is the direction to the center of the resolution element where the object was detected, i. e. the direction to the point $\left(x_{0}, y_{0}\right)$ calculated with relation to the maximum of the directional pattern of the antenna system of $A R_{1}$ or $\mathrm{AR}_{2}$, respectively. This direction for the resolution elements of the joint coverage area is calculated using the expressions (1).

It follows from the above dependences that, within the joint coverage area, the resolution along the azimuthal coordinate is practically independent of the direction to the resolution element, but rather strongly depends on the probe pulse duration. 


\section{The dependence of the resolution on the distance between the aircraft}

To estimate the resolution depending on the distance $D$ between the AR, let us consider the case when the distance to the center of the coverage zone on the $O X$ axis remains constant and equal to $25 \mathrm{~km}$, and the distance $D$ increases from 1 to $10 \mathrm{~km}$.

Figure 5 shows the dependences of the resolution of elements located in the middle of the coverage zone on the distance between the aircraft on which the radars are placed.

It follows from these curves that the distance between the radars of a two-position system plays a significant role in increasing the system resolu-

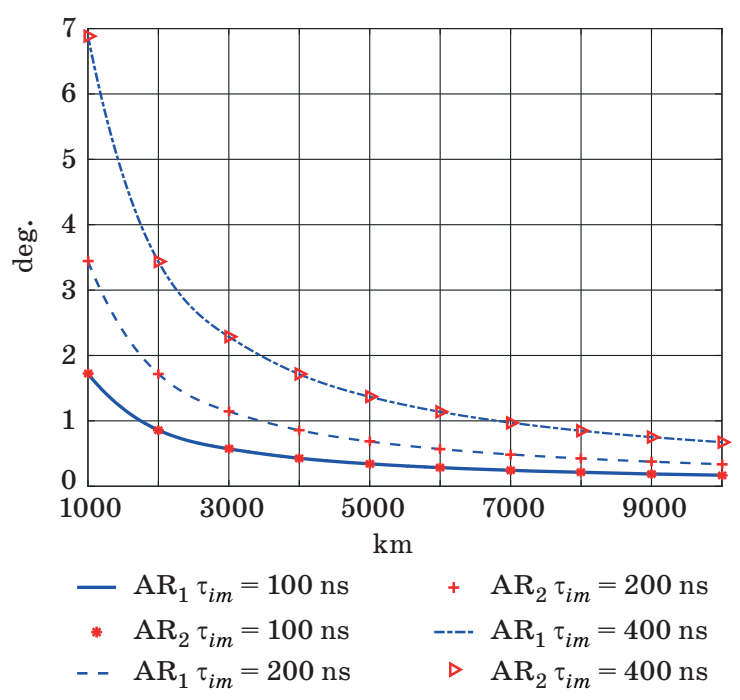

Fig. 5. Dependence of two-position system resolution on the distance between the radars and the probe pulse duration $\tau_{i m}$ tion in angular coordinates. When the distance is equal to zero, the curves approach $\Delta \varphi$, the width of the directional pattern. This is perfectly consistent with the physical representation, as in this case our location becomes unistatic.

\section{Conclusion}

In order to increase the efficiency of using UAVs equipped with small radar systems for automatic or automated detection of physical objects in a given area, it is important to improve the accuracy of determining the coordinates of the detected objects. The azimuthal coordinates are especially difficult to determine. We can make it easier by using multistatic small radars, the simplest of which are two-position airborne ones.

The article provides analytical expressions and curves which can help you choose the best probe pulse duration and the optimal aircraft flight trajectory, increasing the resolution by an order of magnitude or more compared to a single-radar system with the same equipment.

The obtained characteristics of a two-position radar system make it possible to choose the appropriate parameters of small AR systems and UAV flight paths which provide a preset accuracy for the coordinates of detected objects when solving problems related to rapid search for people in a disaster area, or search for sensors during environmental monitoring and assessment of the state of man-made objects.

\section{Financial support}

The reported study was funded by a grant of Russian Science Foundation (project No. 19-79-00303).

tems], 2019, no. 1, pp. 48-56. doi:10.31799/16848853-2019-1-48-56

4. Wattimena M. G., Nenashev V. A., Sentsov A. A., Shepeta A. P. On-board unlimited aircraft complex of environmental monitoring. 2018 Wave Electronics and its Application in Information and Telecommunication Systems (WECONF), Saint-Petersburg, 2018, pp. 1-5. doi:10.1109/WECONF.2018.8604382

5. Toro G. F., Tsourdos A. UAV sensors for environmental monitoring. Belgrade, MDPI, 2018. $661 \mathrm{p}$.

6. Yang R., Li H., Zhang P., Tan L., Gao X., Kang X. High-Resolution Microwave Imaging. Springer, 2018. $552 \mathrm{p}$.

7. Radiolokacionnye sistemy aviacionno-kosmicheskogo monitoringa zemnoj poverhnosti $i$ vozdushnogo prostranstva [Radar systems for aerospace monitoring of the earth's surface and airspace]. V. S. Verba, B. G. Tatarskiy, A. R. Ilchuk, et all 
(Eds.). Moscow, Radiotekhnika Publ., 2014. 576 p. (In Russian).

8. Kim H. G., Park J.-S., Lee D.-H. Potential of unmanned aerial sampling for monitoring insect populations in rice fields. Florida Entomologist, 2018, vol. 101, pp. 330-334.

9. Chen K.-S. Principles of Synthetic Aperture Radar Imaging. A System Simulation Approach. CRC Press, 2016. $217 \mathrm{p}$.

10. Kondratenkov G. S., Frolov A. Yu. Radio vision in the front viewing area of an airborne radar with a synthesized aperture of the antenna. Radioengineering, 2004, no. 1, pp. 47-49 (In Russian).

11. Bhattacharyya S., Mukherjee A., Bhaumik H., Das S., Yoshida K. (eds.) Recent Trends in Signal and Image Processing. Singapore, Springer, 2019. 224 p.

12. Aleshkin A. P., Vladimirov V. V., Nevzorov V. I., Savochkin P. V. Method for increasing the resolution and accuracy of radar angular measurements based on sequential spatio-temporal processing of received signals. Informatsionno-upravliaiushchie sistemy [Information and Control Systems], 2020, no. 2, pp. 37-45 (In Russian). doi:10.31799/1684-88532020-2-37-45

13. Lagovsky B. A. Superresolution, based on aperture synthesis with smart antennas. Antennas, 2013, no. 6 (193), pp. 9-16 (In Russian).

14. Verba V. S. Otsenivaniye dal'nosti i skorosti $v$ radiolokatsionnykh sistemakh [Estimation of range and speed in radar systems]. Part 3. Moscow, Radiotekhnika Publ., 2010. 472 p. (In Russian).

15. Verba V. S. Obnaruzheniye nazemnykh ob"yektov. Radiolokatsionnyye sistemy obnaruzheniya i navedeniya vozdushnogo bazirovaniya [Detection of ground objects. Radar-based airborne detection and guidance systems]. Moscow, Radiotekhnika Publ., 2007. 360 p. (In Russian).

16. Zaitsev D. V. Mnogopozitsionnyye radiolokatsionnyye sistemy. Metody i algoritmy obrabotki informatsii $v$ usloviyakh pomekh [Multipoint radar systems. Methods and algorithms for information processing in terms of interference]. Moscow, Radiotekhnika Publ., 2007. 96 p. (In Russian).

17. Podoplekin Y. F., Nenashev V. A., Shepeta A. P. A method of synthesizing a front antenna aperture earth's surface except the blind zones in the front zone via rocker radar system. The patent for the invention no. 2560082. The priority of the invention, the $01 / 09 / 2014$.

18. Khomyakov A. V., Filipchenkov V. I., Mamon Yu. I. Algorithms for joint trajectory processing in a multi-position radar complex. Bulletin of Tula State University: Technical Sciences, 2016, no. 2, pp. 305-314 (In Russian).

19. Nenashev V. A., Sentsov A. A., and Shepeta A. P. Formation of radar image the Earth's surface in the front zone review two-position systems airborne radar. 2019 Wave Electronics and its Application in Information and Telecommunication Systems (WECONF), Saint-Petersburg, Russia, 2019, pp. 1-5.

20. Nenashev V. A., Kryachko A. F., Shepeta A. P., Burylev D. A. Features of information processing in the onboard two-position small-sized radar based on UAVs. SPIE Future Sensing Technologies, Tokyo, Japan, 2019, pp. 111970X-1-111970X-7.

21. Korzhavin G. A., Nenashev V. A., Shepeta A. P., Podoplekin Yu. F., Davinchuk A. G. (RF) The method of location of targets in the front viewing areas of airborne radar stations of the on-off radar system. The patent for the invention no. 2019108828. The priority of the invention, the $26 / 03 / 2019$.

22. Verba V. S. Aviatsionnyye kompleksy radiolokatsionnogo dozora $i$ navedeniya. Printsipy postroyeniya, problemy razrabotki i osobennosti funktsionirovaniya [Aviation complexes of the radar watch and guidance. Principles of construction, problems of development and features of functioning]. Moscow, Radiotekhnika Publ., 2014. 528 p. (In Russian).

23. Dudnik P. I., Kondratenkov G. S., Tatarsky B. G., Ilchuk A. R., Gerasimov A. A. Aviacionnye radiolokacionnye kompleksy $i$ sistemy [Aviation radar systems and systems]. Moscow, VVIA im. prof. N. E. ZHukovskogo Publ., 2006. 1112 p. (In Russian).

24. Kondratenkov G. S. Aviatsionnyye sistemy radiovideniya [Aviation systems radio vision]. Moscow, Radiotekhnika Publ., 2015. 648 p. (In Russian).

25. Sentsov A. A., Polyakov V. B., Dmitriev V. F. Registration of parameters of movement of the aircraft measuring point at parallel placement of mobile radar stations of a complex of external measurements. Is sues of Radio Electronics, 2019, no. 2, pp. 20-25 (In Russian).

26. Bakulev P. A. Radiolokatsionnie sistemey [Radar systems]. Moscow, Radiotekhnika Publ., 2015. 440 p. (In Russian).

27. Fourati H. (ed.). Multisensor Data Fusion: From Algorithms and Architectural Design to Applications. CRC Press, 2016. 639 p. (Devices circuits and systems).

28. Richard Klemm (ed.). Novel Radar Techniques and Applications. Vol. 2. Waveform Diversity and Cognitive Radar, and Target Tracking and Data Fusion. London, Scitech Publishing, 2017. 553 p.

29. Parshutkin A. V., Levin D. V., Galandzovskiy A. V. Simulation model of radar data processing in a station network under signal-like interference. Informatsionno-upravliaiushchie sistemy [Information and Control Systems], 2019, no. 6, pp. 22-31 (In Russian). doi:10.15217/issn1684-8853.2019.6.22

30. Luchkov N. V. An analysis of radar data multiplexing, time and spatial bindings. Automated Control Systems, 2015, no. 1 (39), pp. 21-26 (In Russian). 
УДК 621.396.96

doi:10.31799/1684-8853-2020-2-31-36

Точностные характеристики определения координат объектов в двухпозиционной системе малогабаритных бортовых РЛС

А. П. Шепета ${ }^{\text {a }}$ доктор техн. наук, профессор, orcid.org/0000-0003-0179-0166, alex@shepeta.com

B. А. Ненашев ${ }^{a}$, канд. техн. наук, доцент, orcid.org /0000-0001-5285-2051

аСанкт-Петербургский государственный университет аэрокосмического приборостроения, Б. Морская ул., 67 , Санкт-Петербург, 190000, РФ

Введение: поиск физических объектов в заданном районе часто осуществляется в автоматическом режиме с помощью малогабаритных беспилотных летательных аппаратов, оборудованных радиолокационными системами. В этом случае антенны бортовых РЛС в силу габаритных ограничений имеют малую апертуру и, соответственно, широкую диаграмму направленности, что снижает точность определения угловых координат обнаруженных объектов. Повышение точности оценки угловых координат приводит к улучшению информативности подобных автоматических систем поиска и, как следствие, к росту эффективности их практического использования. Цель: разработка методики расчета параметров двухпозиционной радиолокационной системы, состоящей из двух малогабаритных бортовых РЛС, расположенных на малых беспилотных летательных аппаратах, обеспечивающих повышение точности определения угловых координат радиоконтрастных физических объектов. Результаты: предложен алгоритм комплексирования данных о координатах физических объектов, обнаруженных в совместной зоне обзора двухпозиционной системы бортовых малогабаритных РЛС, позволяющий, в зависимости от условий наблюдения объектов, увеличить точность определения их азимутальных координат на порядок и более. Рассчитаны траектории летательных аппаратов, на которых достигается повышение точности, и траектории, при которых выигрыш в точности практически отсутствует. Практическая значимость: возможность применять подобные двухпозиционные бортовые малогабаритные РЛС в автоматизированных системах поиска и обнаружения физических объектов и людей в зонах бедствий, экологических катастроф, а также системах сбора и обработки данных информации с датчиков, используемых для мониторинга состояния окружающей среды и техногенных объектов.

Ключевые слова - двухпозиционная система, бортовые РЛС, измерение координат, характеристики точности, малогабаритные летательные аппараты, апертура антенны, диаграмма направленности, комплексирование.

Для цитирования: Shepeta A. P., Nenashev V. A. Accuracy characteristics of object location in a two-position system of small onboard radars. Инфорлационно-управляющие систель, 2020, № 2, с. 31-36. doi:10.31799/1684-8853-2020-2-31-36

For citation: Shepeta A. P., Nenashev V. A. Accuracy characteristics of object location in a two-position system of small onboard radars. Informatsionno-upravliaiushchie sistemy [Information and Control Systems], 2020, no. 2, pp. 31-36. doi:10.31799/1684-8853-2020-2$31-36$ 